Maria Garretoㄹ, Gaspar Gonzalez ${ }^{2}$, Antonio Ramos ${ }^{3}$ and Elizabete Lucas ${ }^{1}$

\title{
LOOKING FOR A MODEL SOLVENT TO DISPERSE ASPHALTENES
}

\author{
${ }^{1}$ Federal University of Rio de J aneiro - Macromolecules Institute - Av. Horacio M acedo, \\ 2030 - Ilha do Fundao, 21941-598, Rio de Janeiro, RJ, Brazil \\ ${ }^{2}$ Petrobras Research Center, Av. Horacio M acedo, 950 - Cidade Universitaria; \\ 21941-915, Rio de Janeiro, RJ, Brazil \\ ${ }^{3} \mathrm{~F}$ ederal University of M aranhao - Department of Chemical Technology, \\ Av. dos Portugueses s/ $n$ - Campus Universitario do Bacanga, 65085-040 - Sao Luis, M A, Brazil \\ Received: July 14, 2010 / Revised: August 28, 2010 / Accepted: October 9, 2010 \\ (C) Garreto M., Gonzalez G., Ramos A., Lucas E., 2010
}

\begin{abstract}
Petroleum could be seen as a system of asphaltenes dispersed in other petroleum components. The petroleum components excluding the asphaltenes are referred to in this paper as Petroleum Medium that Disperses the Asphaltenes - PMDA). This paper proposes a methodology to determine solubility parameter of the PMDA by identifying a model solvent which, when added to the petroleum, does not affect the asphaltenes phase behavior. In order to achieve such objective the asphaltenes precipitation onset $(\mathrm{PO})$ of the petroleum was determined, followed by the identification of a solvent mixture which, when added to the petroleum, does not change the PO. The solubility parameter $(\delta)$ of the PMDA was assumed equal to the solubility parameter of the identified solvent mixture.
\end{abstract}

Keywords: solubility parameter, crude oil, asphaltenes, precipitation onset, organic deposition.

\section{Introduction}

The asphaltenes deposits in the reservoirs, flow lines, refine equipments, and storage tanks have been causing negative impacts to the petroleum production and, depending on the phenomenon extension, can drastically affect the production [1-2]. The asphaltenes tendency to aggregation has been interpreted in function of colloidal and interfacial behaviors, for petroleum and model systems, that is, asphaltenes dispersed in model solvents [3-7]. When studying the petroleum, the asphaltenes precipitation onset induced by the addition of a hydrocarbon solvent (pentane, hexane, heptanes, etc.) is an important parameter since many mathematical models used to predict the asphaltenes precipitation are based on precipitation data [8-14].

The asphaltenes flocculation takes place when solvent addition changes the petroleum composition and, as a consequence, changes the solubility parameter of the asphaltenes dispersion medium [15-16]. The solubility parameters of the petroleum and the asphaltenes fraction have been the properties most widely applied to theoretical developments to describe the asphaltenes precipitation. Several studies using model systems that, in general, do not represent the real conditions and characteristics of the petroleum and its production have been conducted. A better understanding about the interactions between asphaltenes and other petroleum components, as well as interactions between asphaltenes and solvents, is still strongly desirable. Therefore, establishing a model system that can be applied to the evaluation of asphaltenes phase behavior is relevant.

The aim of this work is to establish a solvent mixture in which the asphaltenes reproduce the same phase behavior as in the crude oil. It would be very useful to analyze asphaltenes stabilization in heavy oils.

\section{Experimental}

\subsection{Materials}

A petroleum sample, called Petroleum A, presenting density of $0.9340 \mathrm{~g} / \mathrm{ml}$ and containing $40.2 \mathrm{~m} / \mathrm{m} \%$ of saturates, $33.3 \mathrm{~m} / \mathrm{m} \%$ of aromatics, $23.4 \mathrm{~m} / \mathrm{m} \%$ of resins and $3.1 \mathrm{~m} / \mathrm{m} \%$ of asphaltenes was supplied by Petrobras, Brazil. Several solvents of high purity were used as received: $n$-heptane $(\rho=0.68 \mathrm{~kg} / \mathrm{l}) ; n$-decane $(\rho=0.73 \mathrm{~kg} / \mathrm{l})$; cyclohexane $(\rho=0.78 \mathrm{~kg} / \mathrm{l})$; chloroform $(\rho=1.47 \mathrm{~kg} / \mathrm{l})$. Toluene $(\rho=0.87 \mathrm{~kg} / \mathrm{l})$ was distilled under metallic sodium. All solvents were supplied by Vetec Quimica Fina, Brazil.

\subsection{Determination of Asphaltenes Preci- pitation Onset by N ear Infrared (NIR)}

The asphaltenes precipitation onset (PO) was determined using a near infrared spectrophotometer MATRIX-F-Bruker, containing an external probe (pathway 


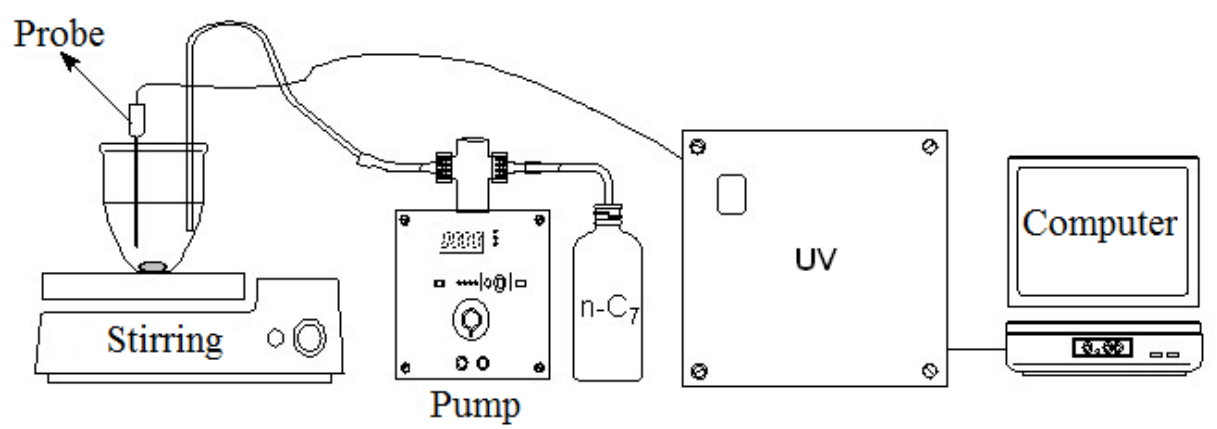

Fig. 1. Scheme of $n$-heptane titration and absorption data acquisition to determine the precipitation onset by NIR

of 2 and $5 \mathrm{~mm})$, coupled with an isocratic pump PU2087 Jasco, that titrates the sample with a flocculant solvent at a flow rate of $2 \mathrm{ml} / \mathrm{min}$ (Fig. 1). The flocculation is monitored by the absorption intensity against volume of flocculant, at $1600 \mathrm{~nm}$. The precipitation onset corresponds to the flocculant volume, added to $1 \mathrm{~g}$ of petroleum which is required to induce the absorption intensity to a minimum value.

In order to validate the result, the precipitation onset of the pure petroleum was also determined by visual observation through an optical microscope. In this procedure, the asphaltenes precipitation from the petroleum was induced by adding $n$-heptane under stirring. At each $0.2 \mathrm{ml}$ of $n$-heptane added an aliquot of the mixture was observed by optical microscopy using an Optical Microscope SZH16, Olympus, coupled with Sony digital camera. The precipitation onset was taken as $\mathrm{ml}$ of $n$-heptane used to observe the first particles of $1 \mathrm{~g}$ of crude oil.

\subsection{Analyses of Pure Petroleum}

The precipitation onset (PO) refers to the minimum amount of flocculant required to induce the precipitation of asphaltenes in $1 \mathrm{~g}$ of petroleum. Due to the size of the essay recipient, the analyses were carried out with about $4 \mathrm{~g}$ of petroleum. Thus, asphaltenes precipitation onset refers to the ratio between the volume of flocculant at minimum absorption intensity and the mass of petroleum (Eq. (1)).

heptane volume at minimum absorption intensity (ml) $\mathrm{PO}$

mass of petroleum $(\mathrm{g})$

\subsection{Analyses of Petroleum Diluted with Solvent (Oil Phase)}

Besides pure petroleum in this work we also analyzed petroleum diluted with a solvent. In this case, we decided to replace the expression " $1 \mathrm{~g}$ of petroleum" by " $1 \mathrm{~g}$ of oil phase". The oil phases were prepared by weighting the petroleum mass and adding a pre-determined volume of solvent. The mass of the oil phase was calculated from the density of the components and the composition of the mixture. The mixture was submitted to ultrasound for $15 \mathrm{~min}$. The following solvents were used to dilute the petroleum: cyclohexane, mixture of decane-toluenecyclohexane (DTC) in different proportions, and mixture of chloroform-toluene-cyclohexane (ChTC). For the systems of petroleum diluted with a solvent, the asphaltenes precipitation onset was calculated from the volume $(\mathrm{ml})$ of $\mathrm{n}$-heptane added to $1 \mathrm{~g}$ of oil phase that is required to achieve the minimum absorption intensity, as shown in Eq. (2).

$$
\mathrm{PO}=\frac{\text { heptane volume at minimum absorption intensity }(\mathrm{ml})}{\text { mass of petroleum }(\mathrm{g})+\text { mass of model-solvent }(\mathrm{g})}
$$

\subsection{Calculus of solubility parameter of solvent mixtures}

The solubility parameters of the solvent mixtures were calculated by the weigh average of the solubility parameters $(\delta)$ and the respective volumetric fractions $(\phi)$ of their pure components according to Eq. (3).

$$
\delta_{\text {mix }}=\left(\delta_{1} \cdot \phi_{1}\right)+\left(\delta_{2} \cdot \phi_{2}\right)+\ldots+\left(\delta_{v} \cdot \phi_{v}\right)
$$

Table 1 presents the solubility parameters of the solvents used in this work [17].

Table 1

Solubility parameters $(\delta)$ of the solvents [17]

\begin{tabular}{|c|c|}
\hline Solvent & Solubility parameter $(\delta), \mathrm{MPa}^{1 / 2}$ \\
\hline$n$-Heptane & 15.3 \\
\hline$n$-Decane & 15.8 \\
\hline Cyclohexane & 16.8 \\
\hline Toluene & 18.2 \\
\hline Chloroform & 19.0 \\
\hline
\end{tabular}

\section{Results and Discussion}

In this preliminary work we used a petroleum sample in which the asphaltenes precipitation onset is easily 
determined by NIR or optical microscopy to make it possible to compare this result with that obtained for the diluted petroleum. In all tests the asphaltenes precipitation was induced by adding $n$-heptane. In this work we consider petroleum as a "mixture of solvents" with asphaltenes "dispersed" in it and this solvent mixture is here called Petroleum Medium that Disperses Asphaltenes (PMDA). If we also consider that the asphaltenes phase behavior in petroleum depends essentially on the solubility parameter $(\delta)$ of the solvent medium (PMDA), this work obtains a more specific objective that is to find a solvent mixture that presents a solubility parameter equal to that of PMDA. Thus, because we did not want to begin the work using random solvent mixtures, presenting random solubility parameters, we tried to determine an approximated value for the solubility parameter of the Petroleum Medium that Disperses Asphaltenes $\left(\delta_{M P D A}\right)$, carrying out analyses of the petroleum diluted with different amounts of $n$-hexane. Then, we have prepared solventmixtures (presenting solubility parameters similar to the calculated one), which was added to the petroleum before starting the procedure to determine the asphaltenes precipitation onset for each system. The solvent which, when added to the petroleum, presents the same asphaltenes precipitation onset value as that for the pure petroleum, is considered a model solvent. The influence of the asphaltenes dilution was not considered, since, as proposed by previous works, the concentration of asphaltenes in model systems does not affect the precipitation onset value.

\subsection{Determination of the Asphaltenes Precipitation Onset in Pure Petroleum ( $\mathrm{PO}_{\text {pure }}$ )}

Initially, we determined the asphaltenes precipitation onset for the pure petroleum. The plot of absorption intensity against volume of flocculant ( $n$-heptane) obtained by NIR (Fig. 2) shows that in the beginning of the analyses the absorption intensity decreases due to the system dilution, and later the absorption starts increasing due to higher scattering caused by the presence of the precipitated asphaltenes particles. Such plot for system containing pure petroleum presents a minimum value of absorption intensity by the addition of $13 \mathrm{ml}$ of $n$-heptane. By dividing this value by the mass of petroleum used for the analyses $(4.0425 \mathrm{~g})$ we get the precipitation onset of $3.2 \mathrm{ml}$ of $n$-heptane/1 gram of petroleum.

On the other hand, the precipitation onset determined for the same petroleum by optical microscopy was $2.7 \mathrm{ml} / \mathrm{g}$. These two precipitation onset values are different, and such results were expected since the two methods are based on distinct fundaments. Nevertheless, these two values are in a good agreement. The detection based on the absorption intensity variation, as already described in the literature [18-19], occurs as follows: when adding the first volumes of flocculant, the absorption intensity decreases due to the system dilution; when the amount of flocculant is sufficient and the asphaltenes precipitate, the absorption intensity increases. Thus, when the first asphaltenes particles of small size appear, a competition between the effects provoked by the dilution and those provoked by the presence of particles in the system takes place. Hence, the minimum value of absorption intensity (indicating the precipitation onset) will be observed when the contribution of the effect caused by the precipitated particles is greater than that of the dilution effect. It means that the asphaltenes molecules start precipitating, in fact, at a flocculant volume smaller than the one that the NIR technique indicates by the minimum value of the absorption intensity. Such statement is confirmed by the asphaltenes precipitation onset value obtained by observing the particle appearance using optical microscopy.

Due to the higher precision provided by the NIR analyses, this technique was used to analyze all systems in this study, hence, the asphaltenes precipitation onset of the pure petroleum used as a reference is that obtained by $\mathrm{NIR}$, that is $\mathrm{PO}=3.2 \mathrm{ml}$ of $n$-heptane $/ \mathrm{g}$ of petroleum.

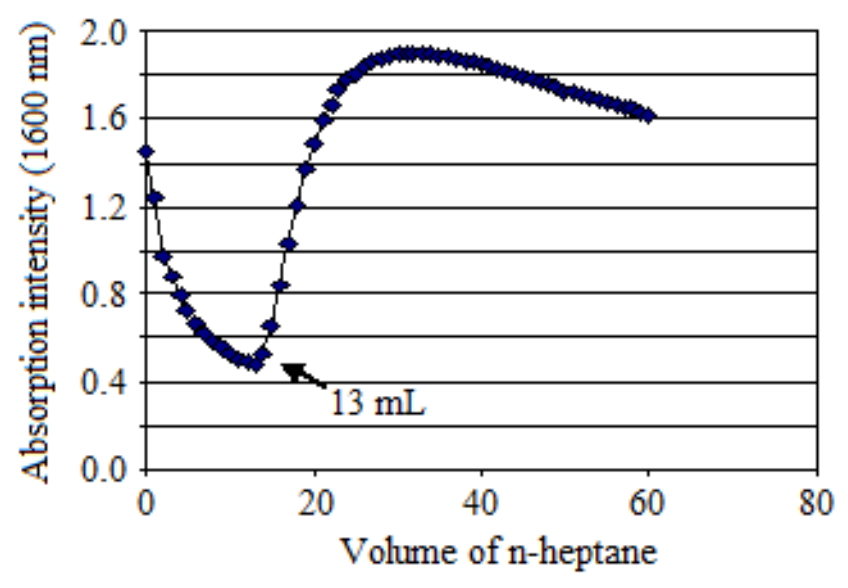

Fig. 2. Absorption intensity against volume of $n$-heptane for the pure Petroleum A at $1600 \mathrm{~nm}$

\subsection{Determination of Asphaltenes Precipitation Onset in Petroleum Diluted with Cyclohexane}

This step of the work was carried out to produce data that would allow calculating the approximate value of the solubility parameter of the Petroleum medium that disperses the asphaltenes $\left(\delta_{P M D A}\right)$. For such purpose, the petroleum was diluted with different amounts of cyclohexane and the volume of $n$-heptane that is required to achieve the asphaltenes precipitation onset was determined for every dilution. Table 2 shows six selected 
dilutions - from 1:5 to 1:30 of petroleum:cyclohexane, highlighting the following values for each of them: volume of cyclohexane added to the petroleum; $n$-heptanes volume at the precipitation onset (determined by NIR); volume fraction of the solvents at the precipitation onset; solubility parameters of both solvents, and the solubility parameter of the solvent mixture (cyclohexane-heptane) at the precipitation onset, which was calculated using Eq. (1). The petroleum volume and its solubility parameter were not taken in account for this calculation.

Two distinct optical paths were used for the measurements, which do not affect the precipitation onset value, but affect the aspect of the so obtained curve of absorption intensity against volume of $n$-heptane: more concentrated systems require smaller optical paths and vice versa.

Using the solvent volume and the flocculant volume for each system and their respective solubility parameter values we determined the solubility parameter of the mixture of these two solvents at the precipitation onset. We expected that the solubility parameter at which the asphaltenes precipitation takes place does not change, as verified in the previous work $[12,16]$. The results presented in Table 2 are in agreement with this statement: the differences among the calculated values can be attributed to the fact that the petroleum contribution to the solubility parameter of the system at the precipitation onset was not taken into account. We can observe that the solubility parameter tends to a constant value $\left(\sim 15.9 \mathrm{MPa}^{1 / 2}\right)$ as dilution of the system because the petroleum contribution becomes less important.

Therefore, the solubility parameter of $15.9 \mathrm{MPa}^{1 / 2}$, that corresponds to the solubility parameter of cyclohexane:heptane mixture $\left(\delta_{m i x}\right)$ at which the asphaltenes started precipitating, was taken as an approximated value of the solubility parameter of the solvent medium.
It is important to mention that the precipitation onset values change in function of the system dilution, even if we consider the sum of petroleum mass and cyclohexane mass (added to the petroleum) as the total mass of the oil phase. The precipitation values obtained for the dilutions of $5,10,15,20,25$ and 30 were, respectively, 2.1, 2.0, $1.9,1.7,1.8$ and $1.8 \mathrm{ml}$ of $n$-heptane/g of oil phase. It means that random selection of the solvent to dilute heavy oil could conduct the asphaltenes precipitation onset values quite far from the real one. In the current study, the values obtained from the dilution are significantly lower than that determined for the pure petroleum, namely $3.2 \mathrm{ml}$ of $n$-heptane/g of petroleum.

\subsection{Approximated Calculation of the Solubility Parameter of the Petroleum Medium that Disperses Asphaltenes $\left(\delta_{\text {PMDA }}\right)$}

As mentioned earlier, $\delta_{P M D A}$ is considered in this study as the solubility parameter of the petroleum components in which the asphaltenes are dispersed, i.e. the petroleum components excluding the asphaltenes. Hence, by mixing PMDA and n-heptane in different volume fractions we achieve a solubility parameter at which the asphaltenes precipitate, that is, the solubility parameter at which the asphaltenes start precipitating follows Eq. (4).

$$
\delta_{\text {mix }}=\left(\delta_{P M D A} \cdot \phi_{P M D A}\right)+\left(\delta_{\text {hept }} \cdot \phi_{\text {hept }}\right)
$$

By using the precipitation onset value obtained for the pure petroleum, i.e. $3.2 \mathrm{ml}$ of $n$-heptane/g of petroleum, we can calculate the total volume of the "solvent" at the precipitation onset as $4.24 \mathrm{ml}: 3.2 \mathrm{ml}$ related to the $n$-heptane $+1.04 \mathrm{ml}$ related to the petroleum mass minus the asphaltenes mass (taking in account the petroleum density).

Table 2

Determination of the near solubility parameter of the solvent mixture (dispersant + flocculant) at the asphaltenes precipitation onset

\begin{tabular}{|c|c|c|c|c|c|c|c|}
\hline $\begin{array}{c}\text { Dilution } \\
\text { Petroleum: } \\
\text { Cyclohexane, } \\
\text { g/ml } \\
(*)\end{array}$ & $\begin{array}{c}\text { Mass of } \\
\text { cyclohexane } \\
\text { added to the } \\
\text { petroleum, } \\
\text { ml }\end{array}$ & $\begin{array}{l}\text { Volume of } \\
\text { heptane } \\
\text { required for } \\
\text { asphaltenes } \\
\text { precipitation, } \\
\text { ml }\end{array}$ & $\begin{array}{c}\text { Volume } \\
\text { fraction of } \\
\text { cyclohexane }\end{array}$ & $\begin{array}{l}\text { Volume } \\
\text { fraction } \\
\text { of } \\
\text { heptane }\end{array}$ & $\begin{array}{c}\delta_{c} \\
\text { cyclohexane, } \\
\mathrm{MPa}^{1 / 2}\end{array}$ & $\begin{array}{c}\delta_{h} \\
\text { heptane, } \\
\mathrm{MPa}^{1 / 2}\end{array}$ & $\begin{array}{c}\delta_{\text {mix }} \\
\text { solvent } \\
\text { mixture } \\
\text { at the } \\
\mathrm{PO}^{* *}, \\
\mathrm{MPa}^{1 / 2}\end{array}$ \\
\hline $1: 5(2)$ & 5 & 10.4 & 0.32 & 0.68 & \multirow{6}{*}{16.8} & \multirow{6}{*}{15.3} & 15.79 \\
\hline $1: 10(2)$ & 10 & 18.0 & 0.36 & 0.64 & & & 15.84 \\
\hline $1: 15(5)$ & 15 & 24.6 & 0.38 & 0.62 & & & 15.87 \\
\hline $1: 20(5)$ & 20 & 29.0 & 0.41 & 0.59 & & & 15.91 \\
\hline $1: 25(5)$ & 25 & 37.2 & 0.40 & 0.60 & & & 15.90 \\
\hline $1: 30(5)$ & 30 & 43.8 & 0.41 & 0.59 & & & 15.91 \\
\hline
\end{tabular}

Notes: * optical path $(\mathrm{mm}) ;$ ** asphaltenes precipitation onset. 
Precipitation onset of asphaltenes induced by the addition of $n$-heptane

Table 3 to petroleum diluted with model solvent

\begin{tabular}{|c|c|c|c|c|c|c|c|c|c|}
\hline $\begin{array}{c}\text { Dilution, } \\
\mathrm{g}: \mathrm{ml}\end{array}$ & Solvent & $\begin{array}{c}\text { Mass of } \\
\text { oil } \\
\text { phase*, } \\
\text { g }\end{array}$ & $\begin{array}{c}\phi_{\text {solv } v} \text { at } \\
\text { PO }\end{array}$ & $\delta_{\text {solv }}, \mathrm{MPa}$ & $\begin{array}{c}\text { Vol. } \\
\text { hep., ml }\end{array}$ & $\begin{array}{c}\text { Vol. hep. at } \\
\text { PO, ml/g oil } \\
\text { phase }\end{array}$ & $\begin{array}{c}\phi_{h e p} \text { at } \\
\text { PO }\end{array}$ & $\delta_{\text {hep, }}, \mathrm{Mpa}$ & $\begin{array}{c}\delta_{P M D A} \text { at } \\
\mathrm{PO}, \mathrm{MPa} \\
1 / 2\end{array}$ \\
\hline \multirow{10}{*}{$1: 1$} & TOLUENE & 1.84 & 0.28 & 18.20 & 6.88 & 3.74 & 0.72 & \multirow{10}{*}{15.3} & 16.12 \\
\hline & DTC( $\left.\begin{array}{lll}5 & 85 & 10\end{array}\right)$ & 1.83 & 0.30 & 17.93 & 6.38 & 3.49 & 0.70 & & 16.08 \\
\hline & DTC(5 8015$)$ & 1.83 & 0.30 & 17.86 & 6.36 & 3.48 & 0.70 & & 16.06 \\
\hline & DTC(10 8010$)$ & 1.83 & 0.30 & 17.80 & 6.27 & 3.43 & 0.70 & & 16.05 \\
\hline & DTC(15/81.5/3.5) & 1.82 & 0.30 & 17.76 & 6.19 & 3.40 & 0.70 & & 16.04 \\
\hline & DTC(15 75 10) & 1.81 & 0.31 & 17.67 & 5.91 & 3.27 & 0.69 & & 16.04 \\
\hline & DTC(10 6525$)$ & 1.81 & 0.31 & 17.59 & 5.87 & 3.24 & 0.69 & & 16.01 \\
\hline & DTC(20 6020$)$ & 1.80 & 0.32 & 17.40 & 5.60 & 3.11 & 0.68 & & 15.97 \\
\hline & DTC(30 50 20) & 1.79 & 0.34 & 17.14 & 5.00 & 2.79 & 0.66 & & 15.93 \\
\hline & DTC(50 3020$)$ & 1.76 & 0.38 & 16.62 & 4.30 & 2.44 & 0.62 & & 15.80 \\
\hline \multirow{10}{*}{$1: 3$} & TOLUENE & 3.58 & 0.27 & 18.20 & 14.19 & 3.96 & 0.73 & \multirow{10}{*}{15.3} & 16.08 \\
\hline & DTC(5 85 10) & 3.55 & 0.29 & 17.93 & 13.03 & 3.67 & 0.71 & & 16.05 \\
\hline & DTC(5 80 15) & 3.55 & 0.29 & 17.86 & 12.50 & 3.52 & 0.71 & & 16.05 \\
\hline & DTC(10 8010$)$ & 3.55 & 0.30 & 17.80 & 12.13 & 3.42 & 0.70 & & 16.05 \\
\hline & $\operatorname{DTC}(15 / 81,5 / 3,5)$ & 3.52 & 0.30 & 17.76 & 12.00 & 3.41 & 0.70 & & 16.04 \\
\hline & DTC(15 75 10) & 3.49 & 0.31 & 17.67 & 11.44 & 3.28 & 0.69 & & 16.03 \\
\hline & DTC(10 6525$)$ & 3.49 & 0.32 & 17.59 & 11.10 & 3.18 & 0.68 & & 16.02 \\
\hline & DTC(20 6020$)$ & 3.46 & 0.33 & 17.40 & 10.48 & 3.03 & 0.67 & & 15.99 \\
\hline & DTC(30 5020$)$ & 3.43 & 0.36 & 17.14 & 9.04 & 2.64 & 0.64 & & 15.96 \\
\hline & DTC(50 3020$)$ & 3.34 & 0.44 & 16.62 & 6.28 & 1.88 & 0.56 & & 15.88 \\
\hline \multirow{10}{*}{$1: 5$} & TOLUENE & 5.32 & 0.26 & 18.20 & 22.20 & 4.17 & 0.74 & \multirow{10}{*}{15.3} & 16.06 \\
\hline & DTC(5 85 10) & 5.27 & 0.27 & 17.93 & 20.46 & 3.88 & 0.73 & & 16.02 \\
\hline & DTC(5 80 15) & 5.27 & 0.28 & 17.86 & 20.16 & 3.83 & 0.72 & & 16.01 \\
\hline & DTC(10 8010$)$ & 5.27 & 0.29 & 17.80 & 19.44 & 3.69 & 0.71 & & 16.01 \\
\hline & $\operatorname{DTC}(15 / 81,5 / 3,5)$ & 5.22 & 0.28 & 17.76 & 19.33 & 3.70 & 0.72 & & 16.00 \\
\hline & DTC(15 75 10) & 5.17 & 0.30 & 17.67 & 17.81 & 3.44 & 0.70 & & 16.01 \\
\hline & DTC(10 65 25) & 5.17 & 0.30 & 17.59 & 17.58 & 3.40 & 0.70 & & 15.99 \\
\hline & DTC(20 6020$)$ & 5.12 & 0.32 & 17.40 & 16.37 & 3.20 & 0.68 & & 15.96 \\
\hline & DTC(30 5020$)$ & 5.07 & 0.35 & 17.14 & 13.63 & 2.69 & 0.65 & & 15.95 \\
\hline & DTC(50 3020$)$ & 4.92 & 0.46 & 16.62 & 8.47 & 1.72 & 0.54 & & 15.91 \\
\hline \multirow{10}{*}{$1: 7$} & TOLUENE & 7.06 & 0.26 & 18.20 & 30.10 & 4.26 & 0.74 & \multirow{10}{*}{15.3} & 16.04 \\
\hline & DTC(5 85 10) & 6.99 & 0.27 & 17.93 & 27.36 & 3.91 & 0.73 & & 16.02 \\
\hline & DTC(5 80 15) & 6.99 & 0.28 & 1786 & 26.50 & 3.79 & 0.72 & & 16.02 \\
\hline & DTC(10 80 10) & 6.99 & 0.29 & 17.80 & 25.40 & 3.63 & 0.71 & & 16.02 \\
\hline & $\operatorname{DTC}(15 / 81,5 / 3,5)$ & 6.92 & 0.29 & 17.76 & 25.20 & 3.64 & 0.71 & & 16.01 \\
\hline & DTC(15 75 10) & 6.85 & 0.30 & 17.67 & 23.50 & 3.43 & 0.70 & & 16.01 \\
\hline & DTC(10 65 25) & 6.85 & 0.31 & 17.59 & 22.70 & 3.31 & 0.69 & & 16.00 \\
\hline & DTC(20 6020$)$ & 6.78 & 0.32 & 17.40 & 21.30 & 3.14 & 0.68 & & 15.97 \\
\hline & DTC(30 5020$)$ & 6.71 & 0.35 & 17.14 & 18.22 & 2.72 & 0.65 & & 15.95 \\
\hline & DTC(50 3020$)$ & 6.50 & 0.44 & 16.62 & 12.22 & 1.88 & 0.56 & & 15.88 \\
\hline
\end{tabular}

* mass of oil phase equal to the sum of model solvent mass and $0.97 \mathrm{~g}$ of PMDA. 
The explanation is that $1 \mathrm{~g}$ of petroleum contains $0.031 \mathrm{~g}$ of asphaltenes, so, in fact, in $1 \mathrm{~g}$ of petroleum we have $0.969 \mathrm{~g}$ of PMDA. By converting grams into milliliters using the petroleum density $\left(0.934 \mathrm{~g} / \mathrm{cm}^{3}\right)$ we calculate the volume of PMDA as $1.04 \mathrm{ml}$. In fact, this is an approximated volume, since it considers the density of petroleum to calculate PMDA that is the petroleum without asphaltenes fraction. However, such calculation can be considered valid since that amount of asphaltenes in the petroleum is very low.

The $\delta_{\text {mix }}$, to be used in Eq. (4) is also an approximated value $15.9 \mathrm{MPa}^{1 / 2}$, which was determined in section 3.2.

By applying such data to Eq. (4) we have: $15.9=\left(\delta_{P M D A} \cdot 0.24\right)+(15.3 \cdot 0.76)$ and so $\delta_{P M D A} \mathrm{H} \approx$ $\approx 17.8 \mathrm{MPa}^{1 / 2}$. That is, the solubility parameter of the solvent mixture (model solvent) that will reproduce the PMDA behavior for the system used in this study should be close to $17.8 \mathrm{MPa}^{1 / 2}$.

\subsection{Looking for a Solvent-Mixture that Reproduces the Asphaltenes Phase Behavior}

We have calculated the near solubility parameter for the model solvent which, when added to the petroleum, does not affect the asphaltenes phase behavior, that is the asphaltenes precipitation onset of the diluted petroleum must be the same as that of the pure petroleum. Therefore, we prepared some solvent mixtures presenting solubility parameters close to $17.8 \mathrm{MPa}^{1 / 2}$, which were then added to the petroleum in different proportions. The asphaltenes precipitation onset $(\mathrm{PO})$ values of all prepared systems were determined. We selected a solvents set of decane/ toluene/cyclohexane (DTC) since it is already being used as model solvent to prepare model systems containing asphaltenes extracted from the petroleum [16] and represents, respectively, saturates, aromatics, and naphthenic petroleum fractions.

Table 3 presents the following data: petroleumsolvent proportions, kind of model solvent used (highlighting the volume proportions of the components), mass of the organic phase (that corresponds to the sum of petroleum mass and model solvent mass calculated from the respective volumes and densities), volume fractions of model solvent and precipitating agent ( $n$-heptane) at the asphaltenes precipitation onset, $n$-heptane volume required to achieve the asphaltenes precipitation onset, solubility parameters of model solvents and $n$-heptane, and solubility parameter of the solvent medium at the asphaltenes precipitation onset (in this case, the $\delta$ of petroleum was considered to be the same as the model solvent). For each group of dilution it is observed that the volume of $n$-heptane required to achieve the asphaltenes precipitation onset changes as a function of the differences in the solubility parameter (thermodynamic quality) of the solvent mixtures used to dilute the petroleum.

Initially, we carried out some measures using model solvents presenting high values of $\delta$ (close to the calculated value $-17.8 \mathrm{MPa}^{1 / 2}$ ). Thus, the model solvent compositions were adjusted to get a system which presented the asphaltenes precipitation onset equal or close to $3.2 \mathrm{ml}$ of $n$-heptane/g of petroleum, that is the PO of pure petroleum induced by the $n$-heptane addition. The tests were also done with the mixture DTC (50:30:20), that has been used in some studies [16] as a model solvent.

The results show that for the selected petroleum the model solvent which, when added to the petroleum, practically does not change the asphaltenes phase behavior is the one presenting $\delta$ of around $17.5 \mathrm{MPa}^{1 / 2}$. Such result proves that random selection of the solvent to dilute petroleum samples, when doing evaluations about asphaltenes stabilization, can produce wrong conclusions. For the petroleum used in this study both cyclohexane and DTC (50:30:20) are not suitable.

It can be observed that by using the $\delta_{\text {mix }}$ value obrtained for the dilution 1:5 (Table 2), Eq. (4) gives $\delta_{P M D A}$ equal to $17.4 \mathrm{MPa}^{1 / 2}$. This value is pretty close to that found for the suitable model solvent. We believe that it is possible to establish a methodology to find suitable model solvents for heavy oils; however, it is necessary to apply the study developed in this work at least to other petroleum that allows determining the asphaltenes precipitation onset without dilution.

Comparison between the asphaltenes precipitation onset for diluted systems using solvent mixture presenting the same solubility parameter

\begin{tabular}{|c|c|c|c|}
\hline $\begin{array}{c}\text { Dilution } \\
\text { Petroleum:solvent }\end{array}$ & $\begin{array}{c}\text { Model solvent } \\
\text { (proportion) }\end{array}$ & $\begin{array}{c}\delta \text { of model } \\
\text { solvent, } \mathrm{MPa}^{1 / 2}\end{array}$ & $\begin{array}{c}\text { Precipitation onset, } \\
\text { ml of heptane/g of } \\
\text { oil phase }\end{array}$ \\
\hline \multirow{2}{*}{$1: 1$} & DTC (15:81.5:3.5) & 17.76 & 3.40 \\
\cline { 2 - 4 } & DTC (1:69.5:29.5) & 17.76 & 3.40 \\
\hline \multirow{2}{*}{$1: 5$} & DTC $(15: 81.5: 3.5)$ & 17.76 & 3.70 \\
\cline { 2 - 4 } & DTC (1:69.5:29.5) & 17.76 & 3.74 \\
\hline \multirow{2}{*}{$1: 5$} & DTC (5:85:10) & 17.93 & 3.88 \\
\cline { 2 - 4 } & ChTC (21:48:31) & 17.93 & 3.48 \\
\hline
\end{tabular}


It is also important to mention that for the same solvent set the system behavior depends only on the thermodynamic quality of the solvent mixture, i.e. solvent mixtures presenting different compositions but keeping constant solubility parameter produce quite similar asphaltenes precipitation onsets, as observed in Table 4. Nevertheless, if a polar component, as chloroform, is used in the solvent mixture composition, the behavior changes. DTC (5:85:10) and ChTC (21:48:31) present the same $\delta=17.93 \mathrm{MPa}^{1 / 2}$ but when used to dilute petroleum the asphaltenes precipitation onsets obtained are 3.88 and $3.48 \mathrm{ml}$ of $n$-heptane/g of oil phase, respectively, .

\section{Conclusions}

It was concluded that diluting petroleum in a nonspecific solvent can generate quite different asphaltenes precipitation onset results from that determined for pure petroleum. It is possible to establish a solvent mixture which, when added to the petroleum, does not affect the asphaltenes phase behavior. For the petroleum used in the present study it is possible to dilute the sample using a mixture constituted of decane/toluene/cyclohexane in the proportion of 10:65:25, respectively, without affecting the asphaltenes phase behavior, i.e. without changing the asphaltenes precipitation onset which was determined for the pure sample. The solubility parameter of such mixture is about $17.5 \mathrm{MPa}^{1 / 2}$. It was also concluded that different proportions of the same solvent mixture, presenting the same solubility parameter, cause similar effect, i.e. they are suitable to dilute petroleum preserving the asphaltenes phase behavior. Nevertheless, such observation is not true for a mixture containing a component with high polarity, such as chloroform, even if its solubility parameter is the same $\left(\delta=17.5 \mathrm{MPa}^{1 / 2}\right)$.

\section{References}

[1] Lucas E., Mansur C., Spinelli L. and Queiros Y.: Pure Appl. Chem., 2009, 81, 473.

[2] Moreira L., Gonzalez G. and Lucas E.: Polimeros Ciencia e Tecnologia, 1998, 8, 46.

[3] Storm D., Sheu E., Detar M. and Barresi R.: Energy \& Fuels, 1994, 8, 567.
[4] Goncalves J., Castillo J., Fernandez A. and Hung J.: Fuel, 2004, 83, 1823.

[5] Spiecker M., Keith L. and Gawrys P.: J. Colloid Interface Sci., 2003, 267, 178.

[6] Khristov K., Taylor S., Czarnecki J. and Masliyah J.: Colloids \& Surfaces, 2000; 174, 183.

[7] Middea A, Monte M. and Lucas E.: Chem. \& Chem. Techn., 2008, 2, 91 .

[8] Zahedi G., Fazlali A., Hosseini S. et al.: J. Petrol. Sci. Eng., 2009, 68, 218.

[9] Levin M. and Redelius P.: Energy Fuels, 2008, 22, 3395.

[10] Pazuki G. and Nikookar M.: Fuel, 2006, 85, 1083.

[11] Mofidi A. and Edalat M.: Fuel, 2006, 85, 2616.

[12] Mutelet F., Ekulu G., Solimando R. and Rogalski M.: Energy \& Fuels, 2004, 18, 667.

[13] Gonzalez G., Souza M. and Lucas E.: Energy \& Fuels, 2006, 20, 2544.

[14] Carbonezi C., Almeida L., Araujo B. et al.: Energy \& Fuels, 2009, 23, 1249.

[15] Rogel E., Leon O., Torres G. and Espidel J.: Fuel, 2000, 79, 389.

[16] Souza M., Oliveira G., Lucas E. and Gonzalez G.: Prog. in Colloid Polym. Sci., 2004, 128, 283.

[17] Burke J.: The Am. Inst. for Conservation, 1984, 13, 13.

[18] Fossen M., Kallevik H., Knudsen K. and Sjoblom J.: Energy \& Fuels, 2004, 21, 1030.

[19] Kyeongseok O., Ring T. and Deo M.: J. Colloid Interface Sci., 2004, 271, 212.

\section{ПОШУК МОДЕЛЬНОГО РОЗЧИННИКА ДЛЯ РОЗЧИНЕННЯ АСФАЛЬТЕНІВ}

Анотація. Розглянуто нафту як систему асфальтенів, диспергованих в інших нафтових компонентах. Такі компоненти, за винятком асфальтенів, отримали назву нафтове середовище, що розчиняс асфальтени (НСРА). У роботі запропоновано методику визначення розчинності НСРА внаслідок ідентифікачії модельного розчинника, який при додаванні до нафти не впливає на фазову поведінку асфальтенів. Визначено початок осаджування асфальтенів (ПВ) з нафти 3 наступною ідентифікачією розчинника, який при додаванні до нафти не змінюе ПВ. Параметр розчинності (ठ) HCPA приймався рівним параметру розчинності розчинника, ідентифікованого таким чином.

Ключові слова: параметр розчинності, сира нафта, асфальтени, початок осаджування, органічні відкладення. 